\title{
Trends in Snakebites Related to Texas Tropical Storms and Hurricanes, 2000-2017
}

\author{
Joann Schulte, DO, MPH ${ }^{1,2}$; Ashley Haynes, $\mathrm{MD}^{2,3}$; Eric Anthony Smith, MSIS ${ }^{2}$; John Fleming, MPA ${ }^{1}$; \\ Kurt Kleinschmidt, $\mathrm{MD}^{2,3}$; Brett Roth, $\mathrm{MD}^{2,3}$ \\ ${ }^{1}$ Houston Health Department, Houston, TX; ${ }^{2}$ North Texas Poison Control Center, Parkland Health and Hospital System, Dallas, TX; ${ }^{3}$ Department of \\ Emergency Medicine, Toxicology Section, UT Southwestern Medical Center, Dallas, TX
}

\begin{abstract}
Introduction-Anecdotal media reports suggest an increase in snakebites after hurricanes. After Hurricane Harvey, several households called Texas poison control centers to report snakebites that occurred when rising water flooded homes. Patterns of snakebite before and after hurricane landfalls have not been well studied.

Methods-We reviewed retrospective surveillance data from the Texas Poison Control Network to examine snakebites possibly related to tropical storms/hurricanes that hit Texas between 2000 and 2017. For that assessment, we compared 2 groups of counties: those designated for individual assistance (impact counties) by the Federal Emergency Management Agency and all others (nonimpact counties). Typically, counties with individual assistance declarations are those in which damage is worse and resident return may be delayed.

Results-Eleven named tropical storms/hurricanes struck Texas between 2000 and 2017; 9 received individual assistance declarations. During the $18 \mathrm{y}, 2037$ snakebites were reported in the $30 \mathrm{~d}$ after and the $30 \mathrm{~d}$ before landfalls in 9 storms; 132 (6\%) occurred poststorm in impact counties, and 13 of $132(9 \%)$ of the case narratives mentioned hurricanes as a contributing factor. Impact counties were not statistically more likely to report snakebites in the $30 \mathrm{~d}$ after landfall for any of the 9 storms or overall, nor did we find differences in patient demographic characteristics, type of snake, and care patterns post- and prestorm.

Conclusions-There was no evidence of increases in snakebites after hurricanes in Texas during the study period. More detailed evaluations may be warranted in other regions that experience hurricanes and have venomous snake populations.
\end{abstract}

Keywords: weather, FEMA, snakes, natural disasters, poison control centers, climate change, disaster declaration

\section{Introduction}

Warnings about possible snakebites related to hurricanes are often issued by the Centers for Diseases Control (CDC) and other public health agencies. ${ }^{1}$ Anecdotal media reports suggest an increase in snakebite after hurricanes, ${ }^{2}$ either immediately after landfall or during the recovery period when debris cleanup is underway.

Corresponding author: Joann Schulte, DO, MPH, Houston Health Department, 8000 North Stadium Drive, Houston, TX 77054; e-mail: joann.schulte@houstontx.gov.

Submitted for publication August 2019.

Accepted for publication January 2020.
In the immediate aftermath of Hurricane Harvey, poison control centers in Texas received calls from Houston about snakebites in homes that flooded after landfall. The occurrence of such reports in Texas is not surprising given the territorial intersection of hurricanes and snakebites. ${ }^{3}$ Hurricanes frequently make landfall along the state's Gulf Coast. Indigenous snake species include the 4 major venomous groups (copperhead, cottonmouth, rattlesnake, and coral snakes), and the geographic range of each includes the southeastern counties most often hit by hurricanes. ${ }^{3}$

Snakebites are not a reportable condition to state health departments ${ }^{4}$ according to CDC definitions. However, poison control centers are often consulted for snakebites because life-threatening complications can develop 
rapidly, ${ }^{5}$ and antivenom treatment is effective but may cost $\$ 100,000$ USD or more. ${ }^{6}$ Poison control centers collect data on each call, and the data are often used for surveillance. ${ }^{7}$ Emergency management and public health agencies often warn of such events, and the warnings may increase awareness of risk.

We used data from the Texas Poison Control Network (TPCN) to evaluate possible increases in snakebite after hurricanes. We hypothesized that the number of snakebites would increase after a hurricane.

\section{Methods}

We used data from the National Weather Service (NWS), Federal Emergency Management Agency (FEMA), and Texas poison control centers for this study. ${ }^{7}$ The Texas Department of State Health Services institutional review board considered this analysis exempt from ethical review.

Our goals were to assess whether any case notes mentioned hurricanes as a contributing factor in poststorm snakebites and to describe the differences in snakebites in the $30 \mathrm{~d}$ after and $30 \mathrm{~d}$ before hurricanes in impact counties compared to all other, nonimpact counties.

\section{NWS DATA AND FEMA DATA AND METHODS}

We reviewed NWS data to develop a list of named hurricanes and tropical storms that made landfall in Texas between 2000 and $2017 .{ }^{8}$ We used FEMA ${ }^{9}$ disaster declarations for individual assistance to construct categories of impact and nonimpact jurisdictions among Texas's 254 counties.

FEMA's individual assistance program ${ }^{9}$ aids individuals and families who have sustained losses due to disasters. Homeowners, renters, and business owners in impact counties who sustained damage to their homes, vehicles, personal property, businesses, or inventory because of the hurricane can apply for FEMA assistance. Disaster assistance includes grants to pay for temporary housing, emergency home repairs, uninsured and underinsured personal property losses, and medical, dental, and funeral costs.

Only some hurricanes or tropical storms receive a disaster declaration that includes individual assistance. In this study, we have analyzed only 9 storms that received a FEMA disaster declaration with individual assistance. Counties with an individual assistance declaration were considered impact counties, and others were classified as nonimpact counties.

\section{TEXAS POISON CONTROL DATA AND METHODS}

Our study was based on telephone calls made to Texas poison control centers, which collect and enter data into the national poison data system (NPDS). Poison control centers offer continuous $\left(24 \mathrm{~h} \cdot \mathrm{d}^{-1}, 7 \mathrm{~d} \cdot \mathrm{wk}^{-1}\right)$ advice and consultation for the public and healthcare providers; calls are made to a toll-free telephone number and are routed based on a caller's area code.

Data collected on each call include exposure information (type of snake and demographic, temporal, and geographic data for the exposed person) and any medical treatment, including antivenom. ${ }^{10}$ Although data variables are transmitted to the NPDS system, the free-text narratives in case notes are only available within the TPCN database.

NPDS has standard generic codes for substances involved in exposures. Snakebites are defined with codes ${ }^{7}$ identifying venomous, nonvenomous, and unknown snakes and include species indigenous to the United States and exotics that are not native.

Using the landfall dates, we obtained Texas poison control data from 2000 to 2017 and limited it to 60 -d periods around the landfall of each storm. We divided the days into 30-d periods after and before each storm and established subsets of Texas counties divided into impact and nonimpact counties using the previously described FEMA individual disaster declarations.

\section{POISON CONTROL DATA COLLECTION AND ANALYSIS}

We reviewed the TPCN call notes of all poststorm bites to determine how often hurricane-related terms were included in the narratives. Search terms included hurricane, tropical storm, wind, flooding, and the specific hurricane names (Table 1). When those terms were found, we reviewed the free-text narrative to note the circumstances of the bite, demographic characteristics of the bitten person, the type of snake, and whether storm issues impeded or delayed medical care.

Table 1. Texas hurricanes and tropical storms by year and FEMA disaster declaration

\begin{tabular}{lll}
\hline Storm name & Year & $\begin{array}{l}\text { FEMA individual } \\
\text { declaration }\end{array}$ \\
\hline Allison & 2001 & Yes \\
Fay & 2002 & Yes \\
Claudette & 2003 & Yes \\
Rita & 2005 & Yes \\
Dean & 2007 & No \\
Erin & 2007 & Yes \\
Dolly & 2008 & Yes \\
Gustav & 2008 & No \\
Ike & 2008 & Yes \\
Alex & 2010 & Yes \\
Harvey & 2017 & Yes \\
\hline
\end{tabular}

FEMA, Federal Emergency Management Agency. 
Table 2. Demographic and exposure characteristics poststorm and prestorm by impact and nonimpact county

\begin{tabular}{lllll}
\hline Characteristic & $\begin{array}{l}\text { Impact county, } \\
\text { poststorm }(n=132) \\
n(\%)\end{array}$ & $\begin{array}{l}\text { Impact county, } \\
\text { prestorm }(n=133) \\
n(\%)\end{array}$ & $\begin{array}{l}\text { Nonimpact county, } \\
\text { poststorm }(n=855) \\
n(\%)\end{array}$ & $\begin{array}{l}\text { Nonimpact county, } \\
\text { prestorm }(n=917) \\
n(\%)\end{array}$ \\
\hline Male & $77(58)$ & $86(65)$ & $512(60)$ & $555(61)$ \\
Mean age (range), y & $32.5(3-79)$ & $33.8(2-88)$ & $33.8(1-95)$ & $32.8(1-84)$ \\
Bitten at home & $114(86)$ & $108(81)$ & $695(81)$ & $722(79)$ \\
Unintentional exposure & $127(96)$ & $127(96)$ & $816(95)$ & $882(96)$ \\
\hline
\end{tabular}

Using FEMA's individual assistance declarations, we split Texas counties into impact and nonimpact categories. We compared snakebites before and after hurricanes in impact and nonimpact counties in a pooled analysis of the 9 storms using descriptive methods and $\chi^{2}$ testing for proportions. Significance indicated by $\mathrm{P}<0.05$.

\section{Results}

\section{STORM SUMMARY}

Eleven named storms struck Texas between 2000 and 2017; 9 received FEMA individual assistance declarations (Table 1). The hurricanes struck 78 of 254 (31\%) Texas counties, and $52(21 \%)$ experienced 2 or more hurricanes. The impact counties were clustered along the southeast Texas coast.

\section{CASE NARRATIVES}

Among the 132 snakebites reported poststorm in impact counties, 13 (9\%) case narrative reports mentioned specific hurricanes (4 in 2005 with Rita, 6 after Ike in 2008, and 3 after Harvey in 2017). Six of the cases were in Houston/ Harris county, and 6 were female. Most bites occurred in residential settings and 2 around hurricane shelters. Twothirds of victims were treated in health care facilities (HCFs), and 4 were lost to follow-up. One case had delayed treatment because flooding impeded ambulance transport.

\section{OVERALL TRENDS}

Texas poison control centers received 2037 calls in the $60 \mathrm{~d}$ pre- and postlandfall for 9 hurricanes. Impact counties reported 265 snakebites; distribution was equal between poststorm $(n=132)$ and prestorm $(n=133)$. Impact counties were not more likely to report snakebites poststorm than were nonimpact counties (132 of 265 vs 855 of $1772 ; P$ value NS).

Men were most commonly bitten $(\mathrm{n}=1237 ; 60 \%)$, and mean age of victims was $33.6 \mathrm{y}$. No significant variation for age or sex (Table 2) was noted poststorm in impact counties compared to nonimpact counties. Most snakebites occurred in the residential/home setting $(\mathrm{n}=1639 ; 81 \%)$ and were unintentional exposures $(\mathrm{n}=1952 ; 96 \%)$. No statistically significant differences between poststorm and impact counties compared to prestorm were noted for sex, mean age, setting of bite, or reason for exposure.

Venomous snakebites were the most commonly reported major category $(n=1207 ; 59 \%)$, followed by unknown snakes $(\mathrm{n}=679 ; 33 \%)$ and nonvenomous bites $(\mathrm{n}=152 ; 8 \%)$. The snakebite categories did not differ significantly poststorm between the impact and nonimpact counties (Table 3).

Copperheads $(n=563 ; 47 \%)$ and rattlesnakes $(n=314$; $26 \%$ ) were the most commonly reported venomous snakes overall (Table 4) and poststorm in impact and nonimpact counties.

Most bite victims $(\mathrm{n}=1835 ; 90 \%)$ were referred (Table 5) to an HCF, where 755 (41\%) were admitted to an intensive care unit $(\mathrm{n}=312 ; 17 \%)$ or to an inpatient unit $(n=443 ; 24 \%)$ or were treated and released $(n=747$; $41 \%)$. Poststorm referrals to HCFs and subsequent care were similar in impact and nonimpact counties; no significant differences were noted in the categories. About a fourth of those bitten received antivenom $(n=457 ; 22 \%)$. Antivenom treatment did not differ significantly poststorm in impact and nonimpact counties.

Table 3. Snakebite by venom status, poststorm and prestorm, impact and nonimpact county

\begin{tabular}{lllll}
\hline Type of snake & $\begin{array}{l}\text { Impact county, } \\
\text { poststorm }(n=132) \\
n(\%)\end{array}$ & $\begin{array}{l}\text { Impact county, } \\
\text { prestorm }(n=133) \\
n(\%)\end{array}$ & $\begin{array}{l}\text { Nonimpact county, } \\
\text { poststorm }(n=855) \\
n(\%)\end{array}$ & $\begin{array}{l}\text { Nonimpact county, } \\
\text { prestorm }(n=917) \\
n(\%)\end{array}$ \\
\hline Venomous & $71(54)$ & $80(60)$ & $497(58)$ & $558(61)$ \\
Not venomous & $10(8)$ & $10(8)$ & $68(8)$ & $64(7)$ \\
Unknown & $51(39)$ & $43(32)$ & $290(34)$ & $295(32)$ \\
\hline
\end{tabular}


Table 4. Categories of venomous snake poststorm and prestorm by impacted county

\begin{tabular}{lllll}
\hline Type of venomous snake & $\begin{array}{l}\text { Impact county, } \\
\text { poststorm }(n=71) \\
n(\%)\end{array}$ & $\begin{array}{l}\text { Impact county, } \\
\text { prestorm }(n=80) \\
n(\%)\end{array}$ & $\begin{array}{l}\text { Nonimpact county, } \\
\text { poststorm }(n=497) \\
n(\%)\end{array}$ & $\begin{array}{l}\text { Nonimpact county, } \\
\text { prestorm }(n=558) \\
n(\%)\end{array}$ \\
\hline Copperhead & $37(52)$ & $37(46)$ & $212(43)$ & $277(50)$ \\
Rattlesnake & $5(7)$ & $16(20)$ & $149(30)$ & $144(26)$ \\
Cottonmouth & $12(17)$ & $8(10)$ & $24(5)$ & $31(6)$ \\
Unknown Crotalid & $10(14)$ & $8(10)$ & $86(17)$ & $82(15)$ \\
Coral snake & $5(7)$ & $10(13)$ & $25(5)$ & $20(4)$ \\
Exotic (nonnative) & $2(3)$ & $1(1)$ & $1(<1)$ & $4(<1)$ \\
\hline
\end{tabular}

\section{Discussion}

Our assessment of Texas poison control data did find that snakebites occur after hurricanes but did not find an increase in snakebites in the hurricane aftermath compared to the period before the hurricane. Nor did we find any significant differences in the demographic characteristics of the persons bitten, the types of snake reported, or medical treatment between exposures that happened poststorm in impact counties compared to nonimpact Texas counties.

Our surveillance assessment of posthurricane snakebites contrasts with some work exploring changes in snakebites associated with disasters and climate change. A recent exploration of rattlesnake envenomations in California found increases in snakebite to be associated with flooding events. ${ }^{11}$ Predictive models have also suggested the range of North American snakes is likely to expand with climate change and increase human risk of venomous snakebites. ${ }^{12}$ However, a study of the storm effects of Hurricane Katrina in Mississippi did not find an increase in venomous snakebites reported to the state's sole poison control center. ${ }^{13} \mathrm{~A}$ limited assessment in 1 site after Hurricane Ike found that $5 \%$ of animal bites were caused by snakes, but changes in such bites were not reported. ${ }^{14} \mathrm{~A}$ study evaluating snakebites in tropical Costa Rica found increased rainfall in dry areas to be associated with more snakebites, but increased precipitation in wet areas was associated with a decrease in snakebites. ${ }^{15}$
Expecting an increase in snakebite after a hurricane seems logical because hurricanes bring tidal surges, increased rain, and flooding. The major kinds of venomous snakes found in Texas (copperheads, rattlesnakes, coral snakes, and water moccasins/cottonmouths) all inhabit environments near the Texas coast that overlap with hurricane strike zones. All 4 types of snakes can swim, and displacement from more secluded locations as a result of flooding would be expected. In addition, debris piles after a hurricane may provide refuge for snakes. However, it is possible the chance of snakebites could decrease in affected counties because residents evacuate before the hurricane and do not quickly return home after the event owing to structural damage to infrastructure and individual homes. In addition, hospitals may be evacuated or inaccessible because of flooding. Reporting of snakebites may also be delayed by disruption in communications, including cell phone towers. All are reasons why posthurricane snakebites may be underreported.

\section{LIMITATIONS}

Information about specific evacuations, levels of flooding, and tidal surge was not available and could have affected the occurrence of and reporting of snakebites. Snakebites were not assessed for 2 storms that did not have FEMA individual assistance declarations because we had no way to compare impact and nonimpact counties. This analysis

Table 5. Medical treatment and antivenom therapy, poststorm and prestorm by impact and nonimpact county

\begin{tabular}{lllll}
\hline Outcomes of HCF referrals & $\begin{array}{l}\text { Impact county, } \\
\text { poststorm }(n=132) \\
n(\%)\end{array}$ & $\begin{array}{l}\text { Impact county, } \\
\text { prestorm }(n=133) \\
n(\%)\end{array}$ & $\begin{array}{l}\text { Nonimpact county, } \\
\text { poststorm }(n=855) \\
n(\%)\end{array}$ & $\begin{array}{l}\text { Nonimpact county, } \\
\text { prestorm }(n=917) \\
n(\%)\end{array}$ \\
\hline HCF referral & $119(89)$ & $121(90)$ & $768(90)$ & $828(90)$ \\
Treat and release & $47(40)$ & $40(33)$ & $326(43)$ & $334(40)$ \\
Admit ICU & $14(12)$ & $21(17)$ & $138(18)$ & $139(17)$ \\
Admit floor & $31(26)$ & $33(27)$ & $180(23)$ & $210(25)$ \\
Lost/No show & $26(22)$ & $27(22)$ & $124(16)$ & $145(18)$ \\
Antivenom therapy & $23(19)$ & $23(19)$ & $201(26)$ & $210(25)$ \\
\hline
\end{tabular}

$\mathrm{HCF}$, health care facility; ICU, intensive care unit 
is based on reports to poison control centers and may not reflect all snakebites treated in regional emergency departments.

\section{Conclusions}

Hurricanes can be a contributing factor in some snakebites to humans; however, no evidence of increased numbers of snakebites was detected poststorm in those counties affected by the recent hurricanes in Texas. Prestorm evacuations and delayed return to damaged and destroyed residences might reduce the number of persons at risk for snakebites after hurricanes. More detailed evaluations may be warranted in other regions that experience hurricanes and have venomous snake populations.

Author Contributions: Study design and concept (JS, AH, JF, BR, KCK); obtaining the data (JS, EAS, BR, KCK); IRB approval (JS, AH, BR, KCK); review of analysis plan and data (JS, EAS, AH, JF, KCK); drafting manuscript (JS, AH, EAS); revision of manuscript (JS, EAS, AH, JF, BR, KCK); final approval of manuscript (JS, AH, EAS, JF, BR, KCK) Financial/Material Support: None.

Disclosures: None.

\section{References}

1. Centers for Disease Control. How to prevent or respond to a snakebite. Available at: https://www.cdc.gov/disasters/ snakebite.html. Accessed June 20, 2019.

2. Bruffliard K. Harvey is also displacing snakes, fire ants and gators. Available at: https://www.washingtonpost.com/ news/animalia/wp/2017/08/28/harvey-is-also-displacingsnakes-fire-ants-and-gators/?utm_term=.3d7fda7719a9. Accessed June 30, 2019.

3. Wozniak EJ, Wisser J, Schwartz M. Venomous adversaries: a reference to snake identification, field safety and bite-victim first aid for disaster-response personnel deploying into the hurricane-prone regions of North America. Wilderness Environ Med. 2006;17(4):246-66.

4. Coates RJ, Stanbury M, Jajosky R, Thomas K, Monti M, Schleiff $\mathrm{P}$, et al. Introduction to the summary of notifiable noninfectious conditions and disease outbreaks - United States. MMWR Morb Mortal Wkly Rep. 2016;63(55):1-4.

5. Gummin DD, Mowry JB, Spyker DA, Brooks DE, Osterthaler KM, Banner W. 2017 Annual report of the American Association of Poison Control Centers' National Poison Data System (NPDS): 35th annual report. Clin Toxicol (Phila). 2018;56(12):1213-415.

6. Boyer LV. On 1000-fold pharmaceutical price markups and why drugs cost more in the United States than in Mexico. Amer J Med. 2015;128(12):1265-7.

7. Schulte J, Domanski K, Smith EA, Menendez A, Kleinschmidt KC, Roth BA. Childhood victims of snakebites: 2000-2013. Pediatrics. 2016;138(5):e20160491.

8. Roth D. Texas hurricane history. National Weather Service. Available at: https://www.weather.gov/media/lch/events/ txhurricanehistory.pdf. Accessed June 18, 2019.

9. FEMA. What FEMA's individual assistance and public assistance programs provide. Available at: https:/www.fema.gov/ news-release/2019/04/03/what-femas-individual-assistanceand-public-assistance-programs-provide. Accessed June 20, 2019.

10. POISINDEX System (electronic version). IBM Watson Health, Greenwood Village, Colorado, USA. Available at: https://www.micromedexsolutions.com. Accessed June 30, 2019.

11. Phillips C, Lipman GS, Gugelmann H, Doering K, Lung D. Snakebites and climate change in California, 1997-2017. Clin Toxicol (Phila). 2019;57(3):168-74.

12. Yanez-Arenas C, Peterson AT, Rodriguez-Medina K, Barve N. Mapping current and future potential snakebite risk in the new world. Clim Change. 2016;134(4): 697-711.

13. Cox R, Amundson T, Brackin B. Evaluation of the patterns of potentially toxic exposures in Mississippi following Hurricane Katrina. Clin Toxicol (Phila). 2008;46(8): $722-7$.

14. Warner GS. Increased incidence of domestic animal bites following a disaster due to natural hazards. Prehosp Disaster Med. 2010;25(2):188-90.

15. Chaves LF, Chuang TW, Sasa M, Gutierrez JM. Snakebites are associated with poverty, weather fluctuations, and El Niño. Sci Adv. 2015;1(8):e1500249. 